\title{
The Risk Factors for the Incidence of Cervical Cancer in Anutapura Hospital of Palu in the Period of 2015-2018
}

\author{
Rosmala Nur ${ }^{1,}$, Nurul Fiyanti Lamato ${ }^{1}$, Nurhaya Suardi Patui ${ }^{1}$, Elvaria Mantao ${ }^{1}$, \\ Rahma Dwi Larasati ${ }^{1}$, Sitti Radhiah ${ }^{1}$, Ulfa Aulia ${ }^{1}$, Syaiful Hendra ${ }^{2}$ \\ ${ }^{1}$ Department of Biostatistics, Demography, and Family Planning, Public Health Study Program, Faculty of Public Health, Tadulako \\ University, Palu City, Indonesia \\ ${ }^{2}$ Department of Information Tecnology Faculty of Engeneering, Tadulako University, Palu City, Indonesia
}

Email address:

nurrosmala09@gmail.com (R. Nur)

${ }^{*}$ Corresponding author

To cite this article:

Rosmala Nur, Nurul Fiyanti Lamato, Nurhaya Suardi Patui, Elvaria Mantao, Rahma Dwi Larasati, Sitti Radhiah, Ulfa Aulia, Syaiful Hendra. The Risk Factors for the Incidence of Cervical Cancer in Anutapura Hospital of Palu in the Period of 2015-2018. European Journal of Preventive Medicine. Vol. 7, No. 4, 2019, pp. 79-83. doi: 10.11648/j.ejpm.20190704.12

Received: June 27, 2019; Accepted: July 18, 2019; Published: August 5, 2019

\begin{abstract}
Background: Cervical cancer is the second leading cause of death after breast cancer in women in developing countries. In 2017, there were $2,8 \%$ cases of patients with cervical cancer in Indonesia and $0,8 \%$ cases in Central Sulawesi. The medical record data of Anutapura Hospital of Palu shows that the incidence of cervical cancer in 2016-2017 was still the biggest disease that occurred in the obstetrics and gynecology department with a total of 36 cases. Objectives: The objectives of this study were to determine the risk of first marriage age, parity, use of oral contraceptives, education level, smoking and use of sanitary napkins at childbearing age on the incidence of cervical cancer in Anutapura Hospital of Palu. Research Patient and Method: This research used quantitative method with case control approach. There were 62 people taken as the case sample and 62 people as the control with age matching. The sampling was conducted using total sampling method. The data used were secondary data in the form of yearly medical record and primary data in the form of interviews and questionnaires. Results: The data analysis conducted using the Odd Ratio test on the results of research showed the followings; the first marriage age $(\mathrm{OR}=4,115$ and $\mathrm{CI}=1,944-8,709)$, parity $(\mathrm{OR}=3,091$ and $\mathrm{CI}=1,485-6,436)$, the use of oral contraceptives $(\mathrm{OR}=3,566$ and $\mathrm{CI}=1,658-7,670)$, education level $(\mathrm{OR}=4,875$ and $\mathrm{CI}=2,263-10,503)$, smoking $(\mathrm{OR}=4,242$ and $\mathrm{CI}=2,229$ $14,446)$, and use of sanitary napkins ( $\mathrm{OR}=5,559$ and $\mathrm{CI}=2,571-12,021)$. Conclusions: First marriage age, risk of parity, use of oral contraception, education level, smoking and use of sanitary napkins are the risk factors for cervical cancer.
\end{abstract}

Keywords: Risk Factor, Cervical Cancer, Parity

\section{Introduction}

Cervical cancer is one type of cancer that often attacks women. The World Health Organization (WHO) states that, every year, thousands of women die from cervical cancer. Cervical cancer attacks the female reproductive organs, precisely in the area of the cervix or the entrance to the uterine area, namely the narrow part of the lower part of the female genitals and uterus $[1,2]$.

Some factors become the risk factors or indirect effect of the growth of Human Papilloma Virus (HPV), so that the cervical precancerous lesions occur, including sexual activity factors which include the age of first sexual intercourse, multiparity, poor genital hygiene, and smoking [3, 4].The prevention of cervical cancer can be done by minimizing the existing risk factors by living a healthy lifestyle, taking an early detection by taking Papanikolaou Test or pap smears for sexually active women. The earlier the early symptoms of cervical cancer are identified, the easier the treatment given $[4,5]$.

The number of cancer patients is estimated to continue to increase from year to year with an estimate of reaching 12 million patients by the year 2030. Every year, there are 6.25 million new patients suffering from cancer. For cervical cancer in the world, it is calculated to occur to more than 30 
per 100,000 population [6]. Cervical cancer is the fourth most common cancer in women, and seventh overall and is the second deadliest cancer in women after breast cancer. About 528,000 new cases of cervical cancer occur and as many as 266,000 die from this disease or accounted for $7.5 \%$ of all deaths caused by cancer in the world $[1,7]$.

In Indonesia, there are more than 15,000 cases of cervical cancer detected every year, and about 8,000 of them dead. Indonesia is a country with the highest number of cervical cancer sufferers in the world. This cancer appears without causing symptoms and is very difficult to detect so that the disease is often diagnosed at the advanced stage $[1,8,9]$.

Based on data obtained from the Indonesian Cancer Foundation (YKI), there were 17.8 million people suffered from cancer in 2016 and 21.7 million people in 2017. There was an increase of $3.9 \%$ for the number of cancer patients. Every year, no fewer than 15,000 cases of cervical cancer occur in Indonesia. Every day, forty women are diagnosed with cervical cancer, and twenty of them die from cervical cancer $[1,10,11]$.

Based on the data obtained from the Provincial Department of Health of Central Sulawesi, the incidence of cervical cancer that occurred in Central Sulawesi in 2015 amounted to 183 cases, decreased to 121 cases, and increased to 133 cases in 2017 [12, 3].

Palu City is in the second place for cervical cancer sufferers in Central Sulawesi and the first place is Donggala Regency. Based on the data obtained from the Regional Department of Health of Palu City there were 87 positive cases of cervical cancer in 2015, 140 cases in 2016 and 68 cases in 2017 [13].

The data obtained from the results of a survey conducted at Anutapura Hospital of Palu, the number of cases of cervical cancer fluctuated in 2015 as many as 15 patients, 28 patients in 2016, 8 patients in 2017 and 11 patients in 2018, in the period of January-July. In 2016-2017, cervical cancer was ranked 9th in the list of the top 10 diseases in the obstetrics, gynecology \& family planning polyclinic of Anutapura Hospital Palu.

\section{Patients and Method}

This research used quantitative research method with an observational analytic approach to determine the risk factors for cervical cancer in patients at the Anutapura Hospital in Palu. This study used a case control design.

This research was conducted in February 2019 in Anutapura Hospital in Palu. The population of this study was divided into two, namely the case population of all cervical cancer patients based on the results of diagnosis by the Obstetrics and gynaecology doctor obtained from the medical record of Anutapura Hospital and the control population who were not female cervical cancer patients.

The case samples in the study were all productive age women (19-58 years) who suffered from cervical cancer based on the results of diagnosis by the Obstetrics and gynaecology doctor obtained from the medical record of Anutapura Hospital as many as 62 people. While the control samples were all productive age women (19-58 years) who did not suffer from cervical cancer as many as 64 people. The sampling was conducted using total sampling.

To find out the relationship between the independent variables and the dependent variable, a computerized data analysis was used to compare the risk factors for cervical cancer between cases and controls, in which the Odd Ratio(OR) formula was used.

\section{Results}

This research was conducted in Anutapura Hospital in February 2019 in order to find out the risk factors of the incidence of cervical cancer in Anutapura Hospital in the period of 2015-2018. The results were as follows:

Table 1. The Risk Factors of the Incidence of Cervical Cancer in Anutapura Hospital.

\begin{tabular}{|c|c|c|c|c|c|c|}
\hline & \multicolumn{4}{|c|}{ Incidence of Cervical Cancer } & \multirow{3}{*}{ Total } & \multirow{3}{*}{$\begin{array}{l}\text { OR } \\
\text { (CI 95\%) }\end{array}$} \\
\hline & \multicolumn{2}{|c|}{ Case } & \multicolumn{2}{|c|}{ Control } & & \\
\hline & $\mathbf{n}$ & $\%$ & $\mathbf{n}$ & $\%$ & & \\
\hline \multicolumn{7}{|c|}{ First Marriage Age } \\
\hline High Risk & 43 & 69,4 & 22 & 35,5 & 65 & 4,115 \\
\hline Low Risk & 19 & 30,6 & 40 & 64,5 & 59 & $(1,944-8,709)$ \\
\hline \multicolumn{7}{|l|}{ Parity } \\
\hline High Risk & 38 & 61,3 & 21 & 33,9 & 59 & 3,091 \\
\hline Low Risk & 24 & 38,7 & 41 & 66,1 & 65 & $(1,485-6,436)$ \\
\hline \multicolumn{7}{|c|}{ Risk of Using Oral Contraceptives } \\
\hline High Risk & 33 & 53,2 & 15 & 46,8 & 48 & 3,566 \\
\hline Low Risk & 29 & 46,8 & 47 & 75,8 & 76 & $(, 658-7,670)$ \\
\hline \multicolumn{7}{|c|}{ Risk of Educational Level } \\
\hline High Risk & 39 & 62,9 & 16 & 25,8 & 55 & 4,875 \\
\hline Low Risk & 23 & 37,1 & 46 & 74,2 & 69 & $(2,263-10,503)$ \\
\hline \multicolumn{7}{|c|}{ Risk of Smoking } \\
\hline High Risk & 11 & 17,7 & 3 & 4,8 & 14 & 4,242 \\
\hline Low Risk & 51 & 82,3 & 59 & 95,2 & 110 & $(1,121-16,046)$ \\
\hline \multicolumn{7}{|c|}{ Risk of Using Sanitary Napkins } \\
\hline High Risk & 45 & 72,6 & 20 & 32,3 & 65 & 5,559 \\
\hline Low Risk & 17 & 27,4 & 42 & 67,7 & 59 & $(2,571-12,021)$ \\
\hline
\end{tabular}

Source: Primary Data 
In Table 1, by using a statistical test, the results obtained show an OR value of 4.115 in CI 95\% 1.944-8.709, means that the risk of women with first marriage age of $<20$ years old (high risk) experiencing cervical cancer incidence 4.1 times greater than women with first marriage age of $\geq 20$ years old (low risk). Since OR $>1$ and the lower limit and upper limit higher than 1, the first marriage age becomes a risk factor and has a significant relationship with the incidence of cervical cancer.

Based on the statistical test, the OR value obtained is 3.091 in CI 95\% 1.485-6.436, means that the risk of women with parity of $>3$ (high risk) experiencing cervical cancer incidence 3.09 times greater than women with parity of $\leq 3$ (low risk). Since $\mathrm{OR}>1$ and the lower limit and upper limit higher than 1, parity becomes a risk factor and has a significant relationship with the incidence of cervical cancer.

Based on the statistical test, the OR value obtained of 3.566 in CI 95\% 1.658-7.670, means that the risk of women who have a history of oral contraceptive use of $\geq 5$ years (high risk) experiencing cervical cancer incidence 3,6 times greater than women with a history of oral contraceptive use of $<5$ years (low risk). Since OR $>1$ and the lower limit and upper limit higher than 1 , the duration of oral contraceptive use becomes a risk factor and has a significant relationship with the incidence of cervical cancer.

Based on the statistical test, the OR value obtained is 4.875 in CI 95\% 2.263-10.503, means that the risk of women who have no school education, elementary, and junior high school level (high risk) experiencing the incidence of cervical cancer 4.87 times greater than women with high school and bachelor level (low risk). Since OR $>1$ and lower limit and upper limit higher than 1, the educational level becomes a risk factor and has a significant relationship with the incidence of cervical cancer.

Based on the statistical test, the OR value obtained is 4.242 in CI 95\% 1.121-15.046, means the risk of women who have a history of smoking (high risk), experiencing cervical cancer incidence 4.2 times greater than women who have no smoking history (low risk). Since OR $>1$ and lower limit and upper limit higher than 1, smoking becomes a risk factor and has a significant relationship with the incidence of cervical cancer.

Based on the statistical test, the OR value obtained is 5.559 in CI 95\% 2.571-12.021, means that the risk of women using sanitary napkins $\leq 3$ times a day (high risk) experiencing cervical cancer incidence 5.56 times greater than women who use sanitary napkins $>3$ times a day (low risk). Since $\mathrm{OR}>1$ and the lower limit and upper limit higher 1 , the use of sanitary napkins becomes a risk factor and has a significant relationship with the incidence of cervical cancer.

\section{Discussion}

Cervical cancer is the primary cancer of the cervix from metaplastic epithelium in the squamocolumnar junction (SSK), which is the transitional area of the vaginal and cervical canal mucosa. This disease is the second most common type of cancer suffered by women around the world, usually affecting women aged 35-55 years old [2, 10, 14].

There are several risk factors that can cause cervical cancer including maternal age, parity, the use of oral contraceptives, education level, smoking, and the use of sanitary napkins. Cervical cancer can be prevented by conducting routine check-up, not having intimate relationships with alternating partners, not having intimate relationships during menstruation period and avoiding having sex before marriage or at a very young age, living a healthy lifestyle, such as maintaining the genital hygiene and avoid smoking, and taking routine screening check [11, 15]

Based on table 1, the incidence of cervical cancer in Anutapura Hospital, women who have their first marriage age of $<20$ years old (high risk) experiencing cervical cancer incidence 4.1 times greater than women who have their first marriage age of $\geq 20$ years old (low risk). Getting married at the age of 20 is considered too young to have sexual relationship and is at risk of cervical cancer 10-12 times greater than those who are married at the age of $>20$ years old. Sexual relationship is ideally done after a woman is truly mature. The maturity is not only seen from menstruation but also depends on mucous cells found in the membranes of the inner skin of the body cavity $[6,16]$.

The incidence of cervical cancer in Anutapura Hospital in women with parity $>3$ (high risk) experiencing the incidence of cervical cancer 3.09 times greater than women with parity $\leq 3$ (low risk). High parity is one of the risk factors for cervical cancer. Women who have many children are estimated to have infection in their cervix, so the occurrence of infections that are too frequent can cause cervical cancer $[14,12]$. During the normal giving birth process, the fetus will pass through the cervix and cause trauma to the cervix, which can trigger the activation of cancer cells. The more often the fetus passes through the cervix, the more often the trauma occurs, and the higher the risk of cervical cancer. Women with parity $>3$ are more at risk for getting cervical cancer $[7,17]$.

The incidence factor of cervical cancer in Anutapura Hospital on the risk of women who have a history of using oral contraceptives of $\geq 5$ years (high risk) experiencing cervical cancer incidence 3, 6 times greater than women with a history of using oral contraceptives $<5$ years (low risk) [11, 18]. The mechanism of using oral contraceptives increases the risk of cervical cancer is still under debate, as it hypothesizes that the thickness of mucus in the cervix due to the use of birth control pills causes cervical cancer. This is because the thickness of the mucus will prolong the presence of a carcinogenic agent in the cervix that is carried through sexual intercourse, including the presence of the HPV virus $[2,19]$.

The incidence of cervical cancer in Anutapura Hospital in women who have no school education, elementary, and junior high school level (high risk)experiencing the 
incidence of cervical cancer 4.87 times greater than women with high school and bachelor level (low risk). A person's level of education can support or influence his/her knowledge[3, 20]. The low level of education is always related to the information and knowledge obtained. The behavior of healthy life is strongly influenced by the education level of the population. Low level of education is one reason for the low level of understanding of the public about health information and healthy lifestyle behaviors[21, $18]$.

The incidence of cervical cancer in Anutapura Hospital in women who have a history of smoking (high risk), experiencing cervical cancer incidence 4.2 times greater than women who have no smoking history (low risk). Tobacco contains carcinogens which are smoked as cigarettes or chewed [1,9].Cigarette smoke produces polycylic aromatic hydrocarbons heterocyclic amine that is highly carcinogenic and mutagenic, while when chewed, tobacco produces nitrosamine. Ingredients derived from smoked tobacco are found in the cervical sap of female smokers and can be cocarcinogens for viral infections $[20,6]$.

The incidence of cervical cancer in Anutapura Hospitals in the risk of women using sanitary napkins $\leq 3$ times a day (high risk) experiencing cervical cancer incidence 5.56 times greater than women who use sanitary napkins $>3$ times a day (low risk). The frequency of using sanitary napkins as a risk for cervical cancer is more related to maintaining the hygiene of genital organs. Regular use of sanitary napkins can prevent pathogenic bacteria that cause disease [12].Sanitary napkins are indeed very important things for women when getting menstruation, but without realizing it, this sanitary napkin is one of the causes of female diseases because of the presence of dioxin substances that can cause cancer [3].

\section{Conclusions}

In this study it was found that the first marriage age, parity, oral contraceptive use, education level, smoking and use of sanitary napkins became the risk factors for cervical cancer with OR values as follows; first marriage age with OR value of 4.1 , parity with OR value of 3.1 , use of oral contraceptives with OR value of 3.6, education level with OR value of 4.9 , smoking with OR value of 4.2 and use of sanitary napkins with OR value of 5.6.It is expected that the government, especially for the Anutapura Hospital, will design a program to prevent the incidence of cervical cancer for women who are at risk and maximize socialization for women of childbearing age who are active in sexual relations and will make more regular check-up such as IVA and Pap smears in an effort to detect the risk of cervical cancer early.

\section{References}

[1] Abd El All HS, Refaat A, Dandash K. Prevalence of cervical neoplastic lesions and human papilloma virus infection in Egypt: National cervical cancer screening project. Infect Agent Cancer. 2007; 2 (1): 1-14.
[2] Gierisch JM, Coeytaux RR, Urrutia RP, Havrilesky LJ, Moorman PG, Lowery WJ, et al. Oral contraceptive use and risk of breast, cervical, colorectal, and endometrial cancers: A systematic review. Cancer Epidemiol Biomarkers Prev. 2013; 22 (11): 1931-43.

[3] Okunowo AA, Daramola ES, Soibi-Harry AP, Ezenwankwo FC, Kuku JO, Okunade KS, et al. Women's knowledge of cervical cancer and uptake of Pap smear testing and the factors influencing it in a Nigerian tertiary hospital. J Cancer Res Pract. 2018; 5 (3): 105-11.

[4] Sulistiowati E, Sirait AM. Knowledge About Risk Factors, Behavior And Early Detection Of Cervical Cancer With Visual Inspection Acetic Acid [Iva] In Women In Central Bogor Sub-district, Bogor City. Bul Penelit Kesehat. 2014; 42 (3): 193-202.

[5] S de Sanjosé, B Serrano, X Castellsagué, M Brotons, J Muñoz, L Bruni FB. HPV and Related Cancers in the GAVI Countries. A WHO/ICO HPV Information Centre Report. Vaccine. 2012; 30 [Suppl 4].

[6] Yost S, Hoekstra A. Cervical cancer in women over 65: An analysis of screening. Gynecol Oncol Reports. 2018; 25 [2017]: 48-51.

[7] Sharma P, Pattanshetty SM. A study on risk factors of cervical cancer among patients attending a tertiary care hospital: A case-control study. Clin Epidemiol Glob Heal. 2018; 6 (2): $83-7$.

[8] Oh HY, Kim MK, Seo S-S, Lee J-K. Association of Combined Tobacco Smoking and Oral Contraceptive Use With Cervical Intraepithelial Neoplasia 2 or 3 in Korean Women. J Epidemiol. 2015; 26 (1): 22-9.

[9] Rio S, Suci EST. Persepsi Tentang Kanker Serviks Dan Upaya Prevensinya Pada Perempuan Yang Memiliki Keluarga Dengan Riwayat Kanker. J Kesehat Reproduks. 2017; 4 (3): 159-69.

[10] Albert A, Lee A, Allbright R, Vijayakumar S. Impact of age on receipt of curative treatment for cervical cancer: an analysis of patterns of care and survival in a large, national cohort. J Geriatr Oncol. 2019 May; 10 (3): 465-74.

[11] Schisler TM, Bhavsar AK, Whitcomb BP, Freeman JH, Washington MA, Blythe JW, et al. Human papillomavirus genotypes in Pacific Islander cervical cancer patients. Gynecol Oncol Reports. 2018; 24 [March]: 83-6.

[12] Segni MT, Demissie HF, Tadesse Dagne Muluand Amdemichael R, Mamo YT, Worku A. Level of Knowledge and Associated Factor toward Cervical Cancer amongWomen Age (21-64) Years Visiting Health Facilities in Gulele SubcityAddis Ababa Ethiopia. J Pancreas. 2017; 18 (1): 44-8.

[13] BKKBN. Sdki 2017. Survei Demografi dan Kesehatan Indonesia. 2017.

[14] Makuza JD, Nsanzimana S, Muhimpundu MA, Pace LE, Ntaganira J, Riedel DJ. Prevalence and risk factors for cervical cancer and pre-cancerous lesions in Rwanda. Pan Afr Med J. 2015; 22: 1-8.

[15] M. S, S. P. S, G. S, N. S. M. A study to assess select risk factors for carcinoma cervix among patients attending Kidwai Memorial Institute of Oncology. Int J Community Med Public Heal. 2017; 4 (11): 4238. 
[16] Di S, Moewardi R, Surakarta K. No Title. 2018.

[17] Setyani RA. Penerapan Program Deteksi Dini Kanker Serviks Sebagai Upaya Pemberdayaan Wanita Di Sleman Yogyakarta. 2017; (2): 12-6.

[18] Machida H, Mandelbaum RS, Mikami M, Enomoto T, Sonoda $\mathrm{Y}$, Grubbs BH, et al. Characteristics and outcomes of reproductive-aged women with early-stage cervical cancer: trachelectomy vs hysterectomy. Am J Obstet Gynecol. 2018; 219 (5): 461.e1-461.e18
[19] Shimamoto K, Saito T, Kitade S, Tomita Y, Nagayama R, Yamaguchi S, et al. A study of treatments and outcomes in elderly women with cervical cancer. Eur J Obstet Gynecol Reprod Biol. 2018; 228: 174-9.

[20] Cooper CP, Saraiya M. Cervical Cancer Screening Intervals Preferred by U.S. Women. Am J Prev Med. 2018; 55 (3): 389-94.

[21] Prayetni. KANKER SERVIKS WANITA USIA SUBUR Cervical Cancer in Productive Women Darmawati. Idea Nurs J. 2007; 1: 9-14. 